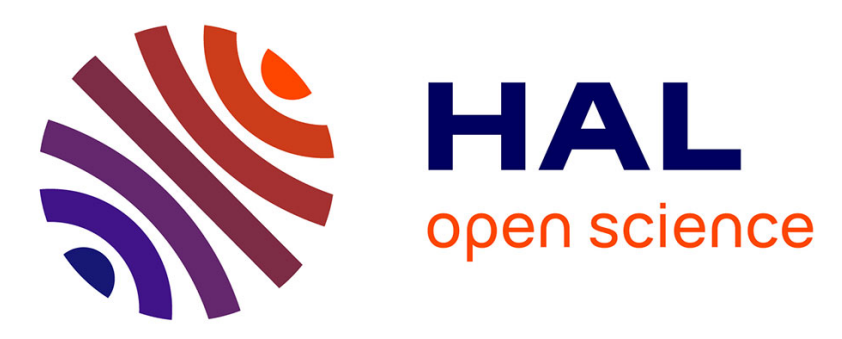

\title{
Inhibition of microbial growth by carbon nanotube networks
}

\author{
Massimiliano Olivi, Elena Zanni, Giovanni de Bellis, Claudio Talora, Maria \\ Sabrina Sarto, Claudio Palleschi, Emmanuel Flahaut, Marc Monthioux, \\ Stefania Rapino, Daniela Uccelletti, et al.
}

\section{To cite this version:}

Massimiliano Olivi, Elena Zanni, Giovanni de Bellis, Claudio Talora, Maria Sabrina Sarto, et al.. Inhibition of microbial growth by carbon nanotube networks. Nanoscale, 2013, vol. 5 ( $\left.\mathrm{n}^{\circ} 19\right)$, pp. 9023-9029. 10.1039/c3nr02091f . hal-01123828

\section{HAL Id: hal-01123828 \\ https://hal.science/hal-01123828}

Submitted on 5 Mar 2015

HAL is a multi-disciplinary open access archive for the deposit and dissemination of scientific research documents, whether they are published or not. The documents may come from teaching and research institutions in France or abroad, or from public or private research centers.
L'archive ouverte pluridisciplinaire HAL, est destinée au dépôt et à la diffusion de documents scientifiques de niveau recherche, publiés ou non, émanant des établissements d'enseignement et de recherche français ou étrangers, des laboratoires publics ou privés. 


\section{OATAO}

\section{Open Archive TOULOUSE Archive Ouverte (OATAO)}

OATAO is an open access repository that collects the work of Toulouse researchers and makes it freely available over the web where possible.

This is an author-deposited version published in : http://oatao.univ-toulouse.fr/ Eprints ID : 13600

To link to this article : DOI:10.1039/c3nr02091f

URL : http://dx.doi.org/10.1039/c3nr02091f

\section{To cite this version :}

Olivi, Massimiliano and Zanni, Elena and De Bellis, Giovanni and Talora, Claudio and Sarto, Maria Sabrina and Palleschi, Claudio and Flahaut, Emmanuel and Monthioux, Marc and Rapino, Stefania and Uccelletti, Daniela and Fiorito, Silvana Inhibition of microbial growth by carbon nanotube networks. (2013) Nanoscale, vol. 5 ( ${ }^{\circ}$ 19). pp. 9023-9029. ISSN 2040-3364

Any correspondance concerning this service should be sent to the repository administrator: staff-oatao@ listes-diff.inp-toulouse.fr 


\title{
Inhibition of microbial growth by carbon nanotube networks
}

\author{
Massimiliano Olivi, $\uparrow^{\mathrm{a}}$ Elena Zanni, $\uparrow^{\mathrm{a}}$ Giovanni De Bellis, ${ }^{\text {bh }}$ Claudio Talora, ${ }^{c}$ \\ Maria Sabrina Sarto, ${ }^{\text {bh }}$ Claudio Palleschi, ${ }^{\text {ah }}$ Emmanuel Flahaut, ${ }^{d}$ Marc Monthioux, ${ }^{e}$ \\ Stefania Rapino, ${ }^{f}$ Daniela Uccelletti ${ }^{* a h}$ and Silvana Fiorito*gh

\begin{abstract}
In the last years carbon nanotubes have attracted increasing attention for their potential applications in the biomedical field as diagnostic and therapeutic nano tools. Here we investigate the antimicrobial activity of different fully characterized carbon nanotube types (single walled, double walled and multi walled) on representative pathogen species: Gram-positive Staphylococcus aureus, Gram-negative Pseudomonas aeruginosa and the opportunistic fungus Candida albicans. Our results show that all the carbon nanotube types possess a highly significant antimicrobial capacity, even though they have a colony forming unit capacity and induction of oxidative stress in all the microbial species to a different extent. Moreover, scanning electron microscopy analysis revealed that the microbial cells were wrapped or entrapped by carbon nanotube networks. Our data taken together suggest that the reduced capacity of microbial cells to forming colonies and their oxidative response could be related to the cellular stress induced by the interactions of pathogens with the CNT network.
\end{abstract}

\section{Introduction}

Investigations into either the dangerous or beneficial effects induced by carbon nanotubes (CNTs) on the biological environment actually represent one of the most explored research fields in the world of biomedical applications of nanoparticles. ${ }^{1,2}$ Behind their exceptional chemical and physical properties, what makes these nanostructures fascinating is their multifaceted behavior when in contact with several animal and human cellular systems, the possibility to tune their properties through chemical modifications and their capacity to be internalized into the cell compartments and to positively interact with some cellular systems (i.e. neuronal and bone cells). Therefore, CNTs can be considered as multifunctional nano tools for future therapeutic and diagnostic purposes. ${ }^{3,4}$

${ }^{a}$ Dept. Biology and Biotechnology, Sapienza-University of Rome, Rome, Italy. E-mail: daniela.uccelletti@uniroma1.it; Fax: +39 0649912351; Tel: +390649912258

${ }^{b}$ Dept of Astronautic, Electrical and Energetic Engineering, Sapienza-University of Rome, Rome, Italy

${ }^{c}$ Dept. Molecular Medicine, Sapienza-University of Rome, Rome, Italy

${ }^{d}$ Universite Paul Sabatier Cirimat/Lcmie, Toulouse, France

${ }^{e}$ Centre d'Elaboration des Matériaux et d'Etudes Structurales, CNRS, University of Toulouse, Toulouse, France

${ }^{f}$ Dept. Chemistry, University of Bologna, Bologna, Italy

${ }^{g}$ Dept. Clinical Medicine, Sapienza-University of Rome, Rome, Italy. E-mail: silvana. fiorito@uniroma1.it; Fax: +39 0649972075; Tel: +390649972078

${ }^{h}$ Research Center on Nanotechnology Applied to Engineering of Sapienza (CNIS), SSNLab, Sapienza-University of Rome, Rome, Italy

$\dagger$ These authors contributed equally to this work.
Several studies demonstrated that CNTs possess antibacterial properties but, while the antimicrobial activity of single-walled carbon nanotubes (SWCNTs) has been widely explored and it has been shown to be higher than that of other CNTs, only a few studies exist on the potential toxic effects of other types of CNTs on pathogen microorganisms. Reports also demonstrated that their functionalization could be a beneficial approach for making them more efficient tools in the disinfection industry. ${ }^{3}$ From time to time, different mechanisms have been evoked in order to explain the CNT cytotoxic effects towards bacteria. The antibacterial activity of CNTs has been shown to be influenced by the same factors that usually affect the behavior of CNTs when in contact with different cell types: their diameter, length, aggregation, concentration, surface functional groups, buffer solution as well as contact time, intensity and, last but not least, the cell type challenged by them..$^{4-8}$ This demonstrated that physical-chemical modifications of CNTs alter their cytotoxicity in bacterial systems. It has been suggested ${ }^{6}$ that individually dispersed nanotubes could be visualized as numerous moving "nano darts" attacking bacteria in a buffer solution, degrading bacterial cell integrity and causing cell death. Moreover, it was demonstrated that the SWCNT electronic structure (i.e., metallic versus semiconducting behaviour) is a key factor regulating SWCNT antimicrobial activity. Experiments were performed with well-characterized SWCNTs of a similar length and diameter but varying fraction of metallic nanotubes. Loss of Escherichia coli viability was observed to raise with an increasing fraction of metallic SWCNTs. ${ }^{9}$ However, despite the huge amount of reports both on the hypothetic and the observed 
mechanisms underlying the interactions between CNTs and microbial cells, this field remains still poorly understood. With this study, we aimed to investigate and compare the toxic effects induced by different nanotube types, namely SWCNTs, double-walled-carbon-nanotubes (DWCNTs) and multi-walledcarbon-nanotubes (MWCNTs) on three typical pathogen microorganisms: Gram-negative Pseudomonas aeruginosa, Gram-positive Staphylococcus aureus, and yeast Candida albicans. Our purpose was also to verify whether the antimicrobial effects depend on the specific chemical and/or physical properties of CNTs.

\section{Experimental}

\section{Synthesis and characterization of carbon nanotubes}

SWCNTs were synthesized by electric arc discharge (Cemes, Toulouse, France) and annealed at $800{ }^{\circ} \mathrm{C}$. DWCNTs were synthesized by Catalytic Chemical Vapour Deposition (CCVD) as described earlier. ${ }^{10}$ Briefly, the Co:Mo-MgO catalyst was reduced in a $\mathrm{H}_{2}-\mathrm{CH}_{4}$ mixture $\left(18 \mathrm{~mol} \% \mathrm{CH}_{4}\right.$, heating and cooling rates $5{ }^{\circ} \mathrm{C} \min ^{-1}$, maximum temperature $1000{ }^{\circ} \mathrm{C}$, no dwell), resulting in a nanocomposite powder which was treated with a concentrated aqueous $\mathrm{HCl}$ solution to extract the CNTs. The acidic suspension was washed until neutrality on a $0.45 \mu \mathrm{m}$ polypropylene filtration membrane. The sample was finally dried overnight at $80{ }^{\circ} \mathrm{C}$. Elemental analysis (flash combustion) gave a carbon content of $89.4 \mathrm{wt} \%$. The BET Specific Surface Area (SSA) was equal to $815 \mathrm{~m}^{2} \mathrm{~g}^{-1}$. Raman analysis $(\lambda=$ $488 \mathrm{~nm}$, not shown) indicated that the mean intensity ratio between the $\mathrm{D}$ and $\mathrm{G}$ bands ( 4 measurements at different places of the sample) was $c a .5 .5 \%$, which corresponds to a very good structural quality.

MWCNTs (CRMD, Orleans, France) were synthesized by a regular catalyst-assisted chemical vapor deposition technique, during which a gaseous hydrocarbon (acetylene) is cracked at $600{ }^{\circ} \mathrm{C}$ in the presence of CoMgO solid solution as a catalyst. Following preparation, exposed catalyst particles were dissolved in a solution of $12 \mathrm{~mol} \mathrm{~L}^{-1} \mathrm{HCl}$. The MWCNTs obtained were used either as prepared and purified before annealing (r-MWCNTs), or after purification by annealing at $2400^{\circ} \mathrm{C}$ under an argon atmosphere (a-MWCNTs). ${ }^{11}$ A full characterization of the two MWCNT samples has been previously performed. The degree of purity and the morphology, structure, and nanotexture of both MWCNT samples, prepared for the in vitro studies, have been previously evaluated by X-ray diffraction, $\mathrm{X}$-ray photoelectron spectroscopy, and transmission electron microscopy (TEM). ${ }^{11}$

The DWCNTs and the two MWCNT samples were also analysed by Cyclic Voltammetry (CV) and Electrochemical Impedance Spectroscopy (EIS) to evaluate their electrical properties. Cyclic Voltammetry on the DWCNT sample on ITO (conducting indium tin oxide-coated glass substrate), showed a redox peak, with $E_{1 / 2}$ potential, at $\sim 70 \mathrm{mV}$ (unpublished results). Cyclic Voltammetry performed on the r-MWCNTs showed a diminished electrical performance with respect to a-MWCNTs: the latter film was in fact largely more conductive and had an increased electrical capacity than that made from the
r-MWCNTs. ${ }^{12}$ Dimensions and chemical characterization of all the CNT samples were performed by TEM and Energy-Dispersive-X-ray analysis (EDX) (see Table 1). For the in vitro studies, the CNT samples were sterilized by heating at $180{ }^{\circ} \mathrm{C}$, washed three times in distilled water, then suspended in $\mathrm{Ca}-$ and $\mathrm{Mg}$ free phosphate buffered saline (PBS) at a stock concentration of $1 \mathrm{mg} \mathrm{ml}{ }^{-1}$. Dimensions and chemical characterization of CNT samples are reported in Table 1.

Dispersion of the CNT samples, suspended in PBS, was performed through a 4 hours gentle sonication, in a bath sonicator at the lowest power, and the dispersed nanotubes were incubated with microbial cells immediately after sonication.

\section{Microbial strains and media}

Pseudomonas aeruginosa ATCC 15692 and Staphylococcus aureus ATCC 25923 bacterial strains were used in this study. For yeast experiments a Candida albicans ATCC 10231 strain was employed. Bacterial strains were grown in LB broth at $37^{\circ} \mathrm{C}$ for 15-16 h. Yeast cells were grown on YPD at $28^{\circ} \mathrm{C}$ for $15-16 \mathrm{~h}$.

\section{Cell viability test}

About $5 \times 10^{7}$ cells per $\mathrm{ml}$ of bacterial or yeast strains were incubated in PBS at $37^{\circ} \mathrm{C}(P$. aeruginosa and $S$. aureus $)$ or at $28^{\circ} \mathrm{C}$ (C. albicans) with CNTs at $100 \mu \mathrm{g} \mathrm{ml}^{-1}$ under shaking for $24 \mathrm{~h}$. We employed the described CNT concentration taking into account that the concentrations used in literature to assay antimicrobial activity of CNTs ranged from 10 to $250 \mu \mathrm{g} \mathrm{ml}{ }^{-1} \cdot{ }^{13-15}$ Aliquots of bacteria or yeast samples were withdrawn, diluted and then spread onto LB or YPD agar plates, respectively. After incubation at the appropriate temperatures, the CFUs were counted. Controls were run without CNT suspensions.

\section{ROS determination}

Flow cytometric analysis was used to assess the production of free intracellular radicals as reported. ${ }^{16}$ Briefly, $5 \times 10^{7}$ microbial cells, either treated or not for $5 \mathrm{~h}$ with CNTs, as described above, or for $1 \mathrm{~h}$ with $100 \mathrm{mM}$ of hydrogen peroxide were washed with PBS and then incubated with dihydrorhodamine 123 (SIGMA) for $2 \mathrm{~h}$. The analysis was conducted by using a FACSCalibur system (BD Biosciences, San Jose, CA) at a low flow rate with excitation and emission settings at 488 and 525 to $550 \mathrm{~nm}$ (filter FL1), respectively.

\section{SEM microscopy imaging of bacterial and yeast cells}

SEM investigation was carried out using a Zeiss Auriga Field Emission SEM (SNN-Lab, Rome, Italy), operated at different accelerating voltages (varying between 2 and $5 \mathrm{keV}$ ) depending on the sample type. Biological samples were prepared according to the procedures described earlier. ${ }^{17}$ Briefly, the morphological changes of bacteria or yeast cells, treated or not with CNTs for $24 \mathrm{~h}$ were investigated by SEM. After exposure, cell suspensions $\left(1.5 \times 10^{8}\right.$ cells $)$ were concentrated by centrifugation at 13000 rpm and quickly fixed with $2 \%$ glutaraldehyde in PBS for $1 \mathrm{~h}$ at RT in the dark. After 3 washes in PBS, cells were suspended in 1\% osmium tetroxide and incubated for $1 \mathrm{~h}$ ( $2 \mathrm{~h}$ for yeast cells) at 


\begin{tabular}{|c|c|c|c|c|c|c|c|c|c|}
\hline \multirow[b]{2}{*}{ CNTs } & \multirow{2}{*}{$\begin{array}{l}\text { Median outer } \\
\text { diameter }\end{array}$} & \multirow[b]{2}{*}{ Length } & \multicolumn{7}{|c|}{ Energy dispersive X-ray analysis (at\%) } \\
\hline & & & $\mathrm{O}$ & $\mathrm{Si}$ & $\mathrm{Ni}$ & Co & $\mathrm{Mg}$ & $\mathrm{Al}$ & $\mathrm{Ti}$ \\
\hline SWCNTs & $1.5 \mathrm{~nm}$ & $\sim 10$ to $20 \mu \mathrm{m}$ & 13.20 & 1.03 & 0.19 & 0.71 & 0.70 & 0.09 & 1.15 \\
\hline DWCNTs & $2 \mathrm{~nm}$ & $\sim 10$ to $20 \mu \mathrm{m}$ & 8.44 & n.d. & n.d. & 0.27 & n.d. & n.d. & n.d. \\
\hline r-MWCNTs & $10-15 \mathrm{~nm}$ & $\sim 100 \mu \mathrm{m}$ & 8.09 & n.d. & n.d. & 0.45 & n.d. & n.d. & n.d. \\
\hline a-MWCNTs & $10-15 \mathrm{~nm}$ & $\sim 100 \mu \mathrm{m}$ & 8.33 & n.d. & n.d. & n.d. & n.d. & n.d. & n.d. \\
\hline
\end{tabular}

$4{ }^{\circ} \mathrm{C}$ in the dark. Following 3 washes in PBS, samples were then dehydrated with sequential treatment with $30,50,70,80,90$, and $96 \%$ ethanol for 10 min each. An aliquot of dehydrated cells, dropped on a silicon wafer and dried at RT, was successively utilized for the electron microscopy analysis as described above.

\section{Results and discussion}

\section{Gram-negative Pseudomonas aeruginosa and Gram-positive Staphylococcus aureus}

P.aeruginosa was used as a representative organism of the class of Gram-negative bacteria. The antibacterial potential was explored by treating P.aeruginosa cells with the different CNT suspensions. We performed the test by measuring the capacity of the bacteria to form colonies, by counting the number of Colony Forming Units (CFU), after their challenge with the four different CNT samples (SWCNTs, DWCNTs, r-MWCNTs and aMWCNTs) dispersed in phosphate buffered saline (PBS) solution at a concentration of $100 \mu \mathrm{g} \mathrm{m} \mathrm{m}^{-1}$. Dimensions and chemical characterization of CNT samples are reported in Table 1. After a cell exposure of $24 \mathrm{~h}$, all CNTs showed a relevant anti-microbial activity resulting in the reduction of the CFU number by about $50-60 \%$, with the r-MWCNT suspension inducing the highest reduction of colony forming units $(60 \%)$ (see Fig. 1A). Moreover, in order to investigate whether oxidative stress could take part in the interaction between CNTs and pathogens, ROS accumulation in microorganisms after $5 \mathrm{~h}$ of contact with CNTs was evaluated by FACS analysis, using hydrogen peroxide as a positive control. All CNT suspensions, apart from SWCNTs, were able to induce a significant ROS production in P.aeruginosa cells (see Fig. 1B). Notably, the most remarkable ROS accumulation was observed in cells exposed to r-MWCNTs (see Fig. 1B). In addition, we carried out SEM analysis to investigate how CNTs interact with cell surfaces. The micrographs (see Fig. 2) gave evidence that P.aeruginosa cells are capable of adhering to CNT aggregates and becoming trapped into the CNT network. Notably, the treatment with SWCNTs, but not with the other CNT types, triggers an intense production of an extra-cellular matrix from the bacteria.

Staphylococcus aureus is an ubiquitous bacterium, that was used to represent the class of Gram-positive bacteria. The CFU analysis performed after $24 \mathrm{~h}$ of cell treatment with CNTs showed that, as observed for P.aeruginosa, DWCNTs, r-MWCNTs and a-MWCNTs induced a severe decrease in CFU number of about $70 \%$ (see Fig. 3A); on the contrary, SWCNTs did not provoke a significant reduction of CFU capacity of S.aureus cells.
Moreover, the cytofluorimetric analysis of ROS production after $5 \mathrm{~h}$ of treatment showed that all CNT samples stimulated ROS accumulation by bacterial cells more than hydrogen peroxide which was used as a control. An increase of ROS positive cells up to $60 \%$ was seen in comparison to untreated cells (see Fig. 3B). SEM images revealed that, also in this case, bacterial cells seemed to be completely wrapped and entrapped by all CNTs (see Fig. 4).

It has been observed that in all cases nanotubes adhere to the cell wall, mostly due to electrostatic interactions. Crawford and coworkers reported that cells adhere most easily to nanostructured surfaces, but attempts to understand the nature of the relationship between surface roughness and cell adhesion failed, and the mechanisms by which surface topography

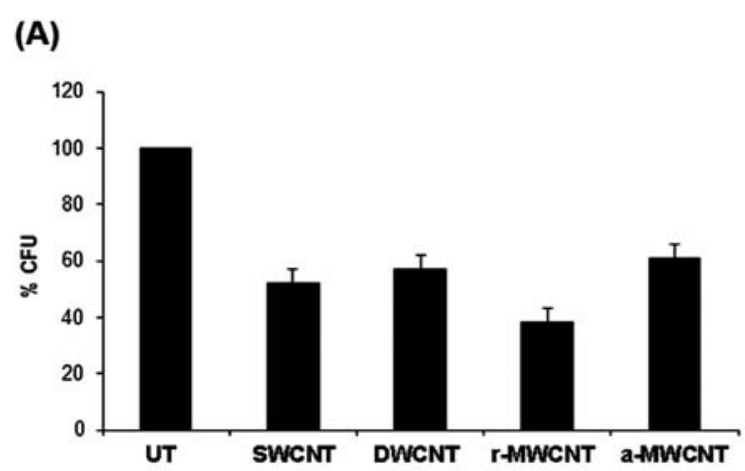

(B)

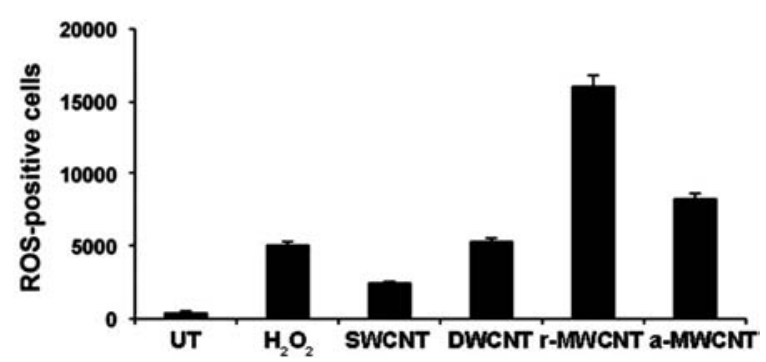

Fig. 1 (A) Antimicrobial activity of CNTs on Pseudomonas aeruginosa bacteria. Cell viability assay was carried out after incubation of $P$. aeruginosa cells $\left(5 \times 10^{7}\right.$ CFU) with the CNT suspensions $\left(100 \mu \mathrm{g} \mathrm{ml}^{-1}\right)$ or PBS only (UT, untreated) for $24 \mathrm{~h}$. Cell survival was monitored by a colony counting method and expressed as a percentage with respect to untreated bacteria incubated with PBS. The error bars indicate SD. (B) Measurement of cellular ROS. FACS analysis of $P$. aeruginosa cells treated for $5 \mathrm{~h}$ with CNTs and then stained for cellular ROS using DHR123 is shown. 50000 events were acquired for all samples. The mean fluorescent intensity of three independent experiments is plotted \pm one standard deviation. 
(A)
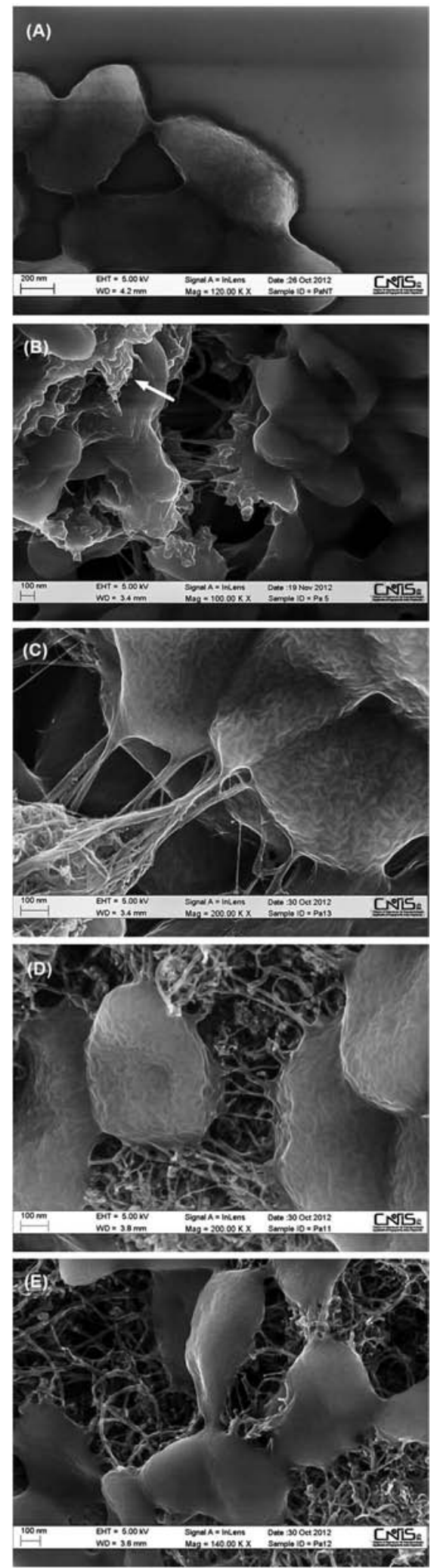

Fig. 2 SEM images of Pseudomonas aeruginosa cells after incubation with PBS for $24 \mathrm{~h} \mathrm{(A)}$ and bacteria after exposure for $24 \mathrm{~h}$ with SWCNTs (B), r-MWCNTs (C), a-MWCNTs (D), DWCNTs (E) suspensions $\left(100 \mu \mathrm{g} \mathrm{ml}^{-1}\right)$. The arrow indicates the extracellular matrix.
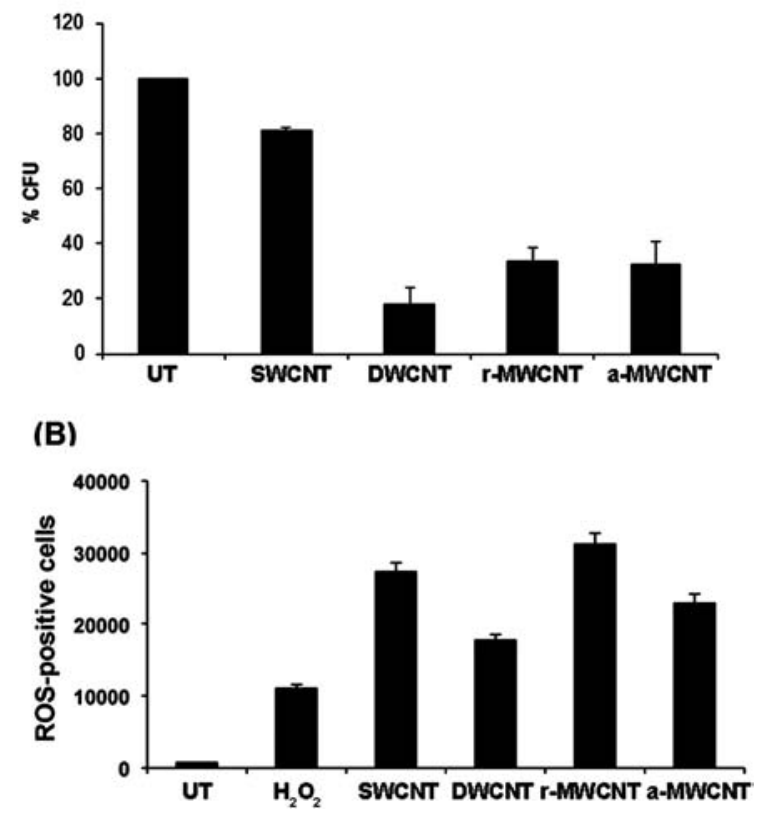

Fig. 3 (A) Antibacterial activity of CNTs on Staphylococcus aureus bacteria. Cell viability assay was carried out after incubation of $S$. aureus cells $\left(5 \times 10^{7} \mathrm{CFU}\right)$ with the CNTs suspensions (100 $\mathrm{g} \mathrm{ml}^{-1}$ ) or PBS only (UT, untreated) for $24 \mathrm{~h}$. Cell survival was monitored by a colony counting method and expressed as a percentage with respect to untreated bacteria incubated with PBS. The error bars indicate SD. (B) Measurement of cellular ROS. FACS analysis of S. aureus cells treated for $5 \mathrm{~h}$ with CNTs and then stained for cellular ROS using DHR123 is shown. 50000 events were acquired for all samples. The mean fluorescent intensity of three independent experiments is plotted \pm one standard deviation.

modulates cell attachment remain rather unclear. ${ }^{18}$ We tested several CNT samples but, despite being very different from each other with respect to dimensions, number of walls, surface chemistry, electronic behavior and presence of residual metal catalysts, no correlation between their physical-chemical characteristics and their antibacterial effect was observed. All the CNT samples induced a significant reduction of CFU production in P.aeruginosa cells and all CNTs, apart from SWCNTs, induced a significant reduction of CFU in S.aureus cells. Regarding ROS production, the only difference in the effects exerted by the CNTs concerns their pro-oxidative attitude, with SWNTs being much less effective in inducing ROS production in P.aeruginosa cells, whereas this was not the case for S.aureus cells. In addition, any relationship was shown between the electrical properties of the CNTs tested and their cytotoxic effect against bacterial cells. In a recent study the antibacterial effects of SWCNTs were correlated with CNT electronic structure. Loss of Escherichia coli viability was positively correlated with the fraction of metallic SWCNTs in samples of similar diameter, length, and number of defect sites. Moreover, the authors highlighted that, because of the extent of positive correlation between the glutathione oxidation and the fraction of metallic SWCNTs, the increased cytotoxicity could be due to increased cellular oxidative stress. ${ }^{9}$ In our study any correlations were observed between CNT antibacterial effects and their electrical properties. In fact, the most electro-conductive a-MWCNTs did 

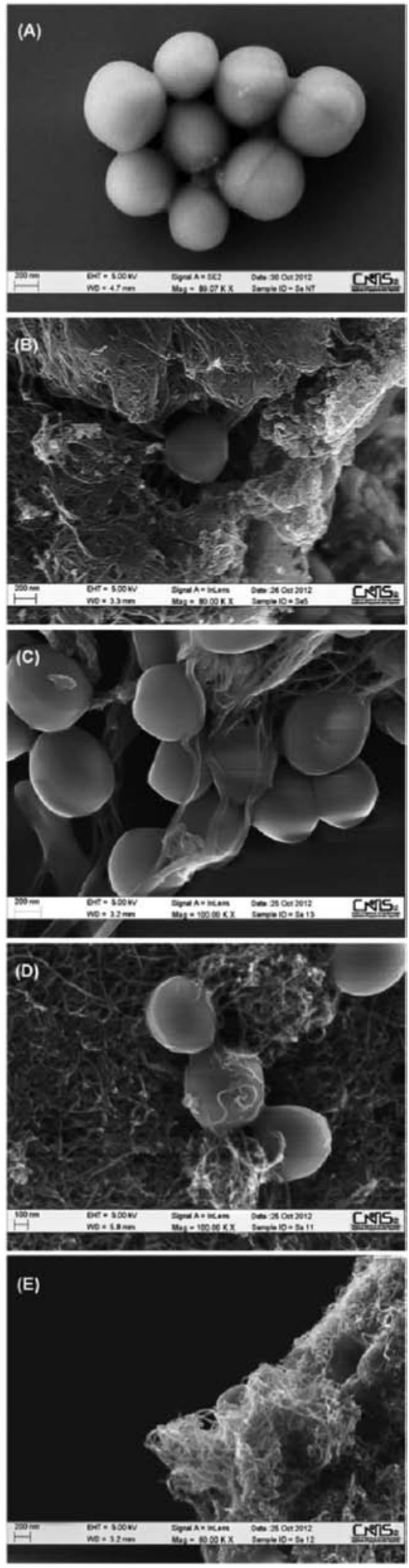

Fig. 4 SEM images of Staphylococcus aureus cells after incubation with PBS for $24 \mathrm{~h}(\mathrm{~A})$ and bacteria after exposure for $24 \mathrm{~h}$ with SWCNTs (B), r-MWCNTs (C), aMWCNTs (D) or DWCNTs (E) suspensions $\left(100 \mu \mathrm{g} \mathrm{ml}^{-1}\right)$. not result as more cytotoxic against bacteria than the less conductive r-MWCNTs, which are similar in diameter and length. In addition, despite the active redox capacity of DWCNTs (unpublished results), they were not observed to induce a higher production of ROS than the other CNTs.

Our findings, demonstrating the increase in the bacterial biofilm formation by P.aeruginosa induced by the SWNT sample and the adhesion of all bacterial species to CNTs are in agreement with literature data showing the influence of nanoscale surface morphology on prokaryotic cell attachment. Several studies reported that bacterial adhesion and biofilm formation on nanostructured surfaces are significantly influenced by nanoscale morphological features. ${ }^{19}$ Moreover, it has been found that SWNTs affect bacterial growth and biofilm formation, enhancing after $48 \mathrm{~h}$ of exposure both the total cell growth and biofilm formation of Escherichia coli. ${ }^{6}$ We observed that SWCNTs possess a different antibacterial behavior towards Gram-positive $S$. aureus as compared to Gram-negative P. aeruginosa. The Gram-positive bacteria cell wall consists of a $\sim 20-$ $30 \mathrm{~nm}$ thick layer of peptidoglycan into which teichoic acids are embedded. The total cell wall can be $50-150 \mathrm{~nm}$ thick. ${ }^{20}$ On the contrary, the Gram-negative bacteria, even though they have a thinner peptidoglycan layer which represents $10 \%(\sim 3-8 \mathrm{~nm})$ of the total cell wall $(30-80 \mathrm{~nm}),{ }^{21}$ possess an outer membrane that gives them different characteristics compared to Gram-positive bacteria. Recently, Liu and coworkers $^{6}$ investigated the mechanical properties of the bacterial cell surface by atomic force microscopy in aqueous solution. Their results indicated that Gram-positive species had softer surfaces than the Gramnegative ones. All the above considerations suggest that the different composition of the bacterial cell wall and its mechanical characteristics could influence the CNT antibacterial capacity.

In several studies it has been reported that SWCNTs exhibit stronger antibacterial activities compared to other CNT types, and different mechanisms have been hypothesized to influence this capacity. ${ }^{2,7,22}$ SWCNTs were shown to exhibit antibacterial properties against both Salmonella enterica and Escherichia coli in a dose-dependent manner, ${ }^{23}$ indicating that nanotube concentration is a relevant factor in the antibacterial effect. Others correlated the antibacterial activity of SWCNTs with the CNT electronic structure and the subsequent increased cellular oxidative stress. ${ }^{9}$ At present, literature data do not allow us to draw any conclusions on which type of CNTs possesses higher or lower antibacterial properties. Accordingly to Akasaka and Watari's findings, ${ }^{24}$ we showed that bacterial cells closely adhere to nanotubes becoming entrapped into the CNTs network. Capture of bacteria Streptococcus mutans with flexible carbon nanotubes, SWCNTs or MWCNTs was observed in vitro. It has been shown that MWCNTs with an average diameter of 30 $\mathrm{nm}$ had the highest adhesive capacity; the precipitation efficiency was due to both their adequate dispersibility and aggregation activity. ${ }^{24}$ In addition, the effects induced by SWCNTs on cell morphology and mechanical properties of two typical bacterial models, such as the Gram-negative Escherichia coli and the Gram-positive Bacillus subtilis, were reported. ${ }^{25}$ In particular, individually dispersed SWCNTs develop nanotube 
networks on the cell surface, destroying the bacterial envelopes with consequent leakage of the intracellular content. Bacteria have been demonstrated to attach to activated carbon particles by means of strong van der Waals forces between the bacterial and the carbon surfaces. ${ }^{26}$ Therefore, it is likely that all types of carbon-based nanomaterials, and especially nanotubes, have a high affinity for bacteria as a result of van der Waals forces. This mechanism can explain how carbon nanotubes induce the sequestering of bacterial cells.

Recently, the impact of CNTs to human gut microbes has been investigated. CNTs lysed the walls and membranes of the bacteria, depending on the length and surface functional groups of the CNTs as well as the shapes of the microbes. ${ }^{27}$

\section{Yeast Candida albicans}

The antimycotic effect of CNTs was investigated by using the opportunistic pathogen Candida albicans. Yeast cells were challenged for $24 \mathrm{~h}$ with CNTs and the CFU were counted (see Fig. 5A). No toxicity was reported with SWCNT exposure. By contrast, a slight reduction in the CFU occurred in cells treated with both MWCNT samples. DWCNTs showed the highest antimycotic activity inducing a CFU reduction of $60 \%$. The ROS production was then evaluated as described above for the

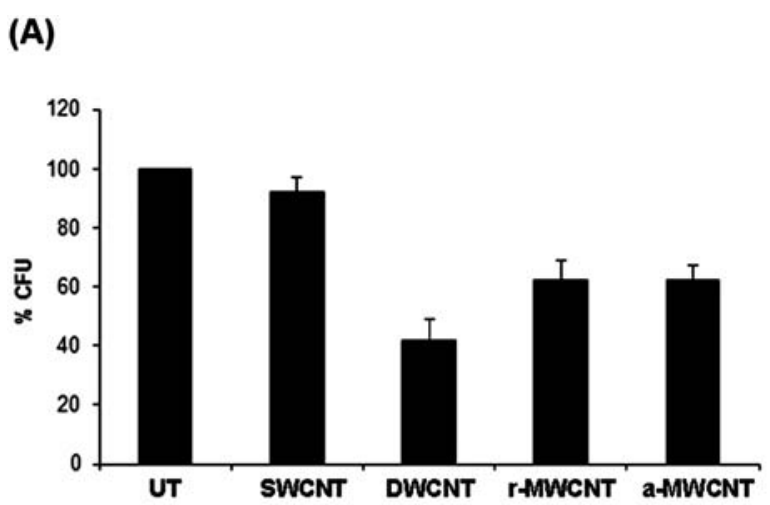

(B)

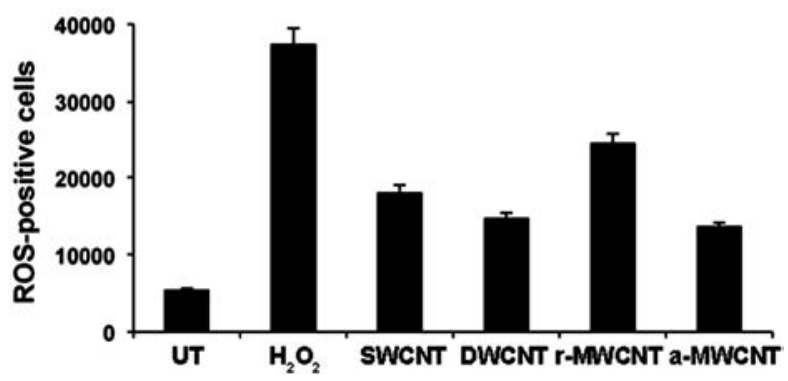

Fig. 5 (A) Antimycotic activity of CNTs on Candida albicans yeast. A cell viability assay was carried out after incubation of $C$. albicans cells $\left(5 \times 10^{7} \mathrm{CFU}\right)$ with the CNT suspensions $\left(100 \mu \mathrm{g} \mathrm{ml}^{-1}\right.$ ) or PBS only (UT, untreated) for $24 \mathrm{~h}$. Cell survival was monitored by a colony counting method and expressed as a percentage with respect to untreated yeast cells incubated with PBS. The error bars indicate SD. (B) Measurement of cellular ROS. FACS analysis of $C$. albicans cells treated for $5 \mathrm{~h}$ with CNTs and then stained for cellular ROS using DHR123 is shown. 50000 events were acquired for all samples. The mean fluorescent intensity of three independent experiments is plotted \pm one standard deviation. bacterial species. All CNT suspensions were capable of inducing high levels of ROS, with a fraction of positive cells ranging from 30 to $50 \%$ (see Fig. 5B). In this case, r-MWCNTs resulted to have the highest oxidative potential. Finally, a surface analysis on treated yeast cells was performed by SEM. Fig. 6 shows that all CNTs were able to contact and damage the cell wall, by means of punctuations caused by CNT bundles entering inside the cells. The data reported here strongly argue that the damage to the cell envelope was an early effect that, in turn, caused the CFU reduction.

Worth noting, a different CNT-cell interaction seems to occur in the eukaryotic cells with respect to bacteria and this could be accounted for by a completely different cell wall chemistry and structure. With this kind of analysis we cannot ascertain how deeply the CNT bundles enter inside the cells. We hypothesize that they reach at least the cell membrane and that the subsequent interactions between the CNT chemical surface groups and cell the constituents affect the intracellular redox balance, as supported by the increased ROS production.
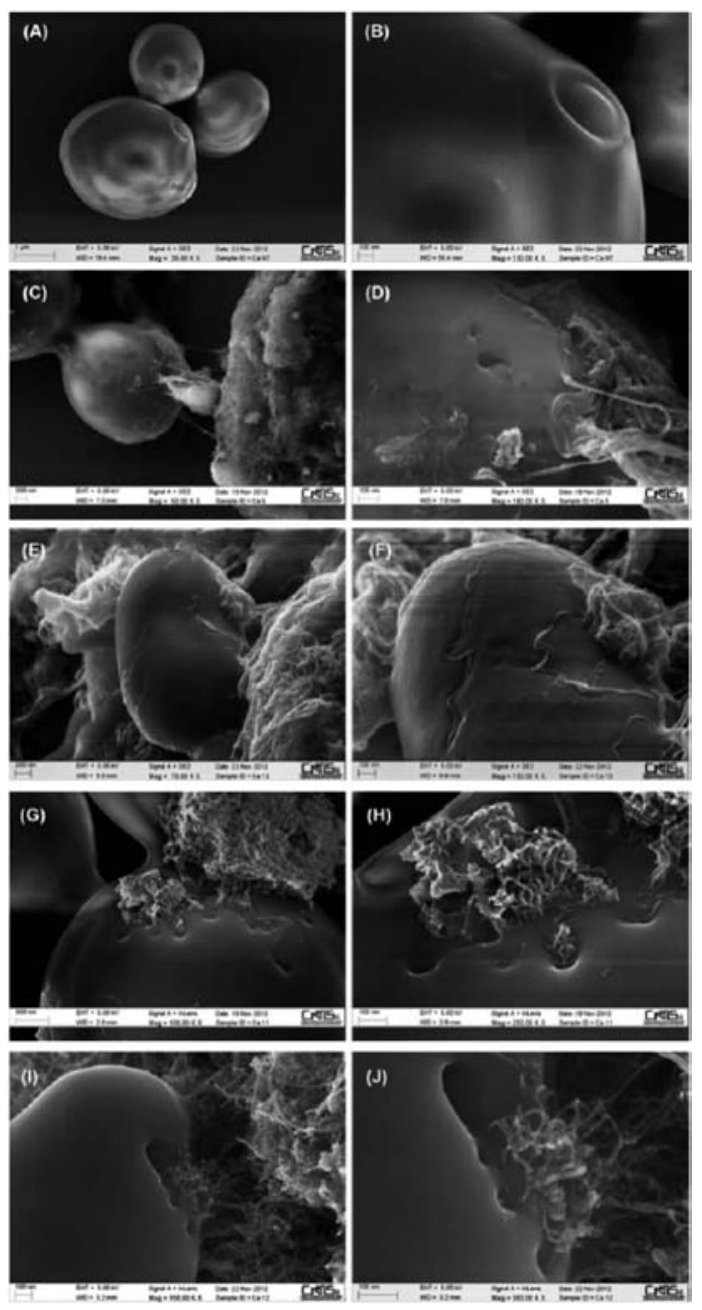

Fig. 6 SEM images of Candida albicans cells after incubation with PBS for $24 \mathrm{~h}$ ( $\mathrm{A}$ and $\mathrm{B}$ ) and yeast cells after exposure for $24 \mathrm{~h}$ with SWCNTs (C and D), or r-MWCNTs (E and F), a-MWCNTs (G and H), DWCNTs (I and J) suspensions $\left(100 \mu \mathrm{g} \mathrm{ml}^{-1}\right)$. 
For the first time an intrinsic antifungal activity of CNTs is here highlighted. To date it has been observed that CNTs show antifungal activity only when conjugated with the antimycotic drug Amphotericin B (AMB), improving its therapeutic activity while decreasing its toxicity. By contrast, any antifungal activity was found to be possessed by CNTs without AMB. ${ }^{28}$ The data reported here strongly argue that the injury to the cell wall is an early effect and, possibly, also the main cause of CFU reduction in the yeast population.

\section{Conclusions}

Here we reported that four CNT types, differentiated by their synthesis, dimensions, surface chemistry, electrical properties, aggregation capacity and metal catalyst amount, all possess antimicrobial activity towards both Gram-positive and Gramnegative bacteria and yeast cells. Induction of ROS production in these pathogens, even though to a different extent, was also observed. These effects could not be correlated to any specific CNT chemical-physical characteristics but could be ascribed to the ability of CNT networks to attract and capture pathogens through van der Waals forces. Moreover, to investigate whether CNTs could affect the membrane integrity of the microorganisms, we analysed the release of nucleic acids from the cells. No difference was observed between the cells treated with the different CNTs and the untreated cells (data not shown). This finding supported our hypothesis that a wrapping, rather than a piercing effect could be responsible for the observed reduced capacity of forming colonies by the pathogens.

Our investigation highlights that different carbon nanotube preparations possess remarkable antibacterial properties not clearly related to CNT specific characteristics, but to the direct interaction with the microbial pathogen wall, that will deserve further investigation.

Many microorganisms are responsible for serious infections in humans, including Staphylococci, Streptococci, Salmonella and Candida among many others. The usual medical treatment for such infections involves the application of antimicrobial agents, such as antibiotics and chemotherapeutic agents. However, the microbial pathogens, due to the frequent and unsuitable use of antibiotics, became resistant to the standard antimicrobial treatments, inducing an increase in the public health risks. Thus, it is imperative to find out effective alternative approaches, not harmful to healthy cells and living organisms, for treating such antimicrobial resistant strains. These results confirm that CNTs possess the intrinsic potential to act as antibacterial tools that could be exploited in biomedical devices and/or in filtering systems for hospital and industrial cleaning applications.

\section{Notes and references}

1 E. Taylor and T. J. Webster, Nanomedicine, 2011, 6, 1463.

2 M. Prato, K. Kostarelos and A. Bianco, Acc. Chem. Res., 2008, 41, 60.

3 S. Kang, M. S. Mauter and M. Elimelech, Environ. Sci. Technol., 2008, 42, 7528.
4 S. Kang, M. Pinault, L. D. Pfefferle and M. Elimelech, Langmuir, 2007, 23, 8670.

5 S. Kang, M. Herzberg, D. F. Rodrigues and M. Elimelech, Langmuir, 2008, 24, 6409.

6 S. B. Liu, L. Wei, L. Hao, N. Fang, M. W. Chang, R. Xu, Y. H. Yang and Y. Chen, ACS Nano, 2009, 3, 3891.

7 L. R. Arias and L. J. Yang, Langmuir, 2009, 25, 3003.

8 S. Kang, M. S. Mauter and M. Elimelech, Environ. Sci. Technol., 2009, 43, 2648.

9 C. D. Vecitis, K. R. Zodrow, S. Kang and M. Elimelech, ACS Nano, 2010, 4, 5471.

10 E. Flahaut, R. Bacsa, A. Peigney and C. Laurent, Chem. Commun., 2003, 1442.

11 S. Fiorito, M. Monthioux, R. Psaila, P. Pierimarchi, M. Zonfrillo, E. D'Emilia, et al., Carbon, 2009, 47, 2789.

12 A. Serafino, A. R. Togna, G. I. Togna, A. Lisi, M. Ledda, S. Grimaldi, J. Russier, F. Andreola, M. Monthioux, F. Béguin, M. Marcaccio, S. Rapino, F. Paolucci and S. Fiorito, Nanomed.: Nanotechnol., Biol. Med., 2012, 8, 299.

13 R. Su, Y. Jin, Y. Liu, M. Tong and H. Kim, Colloids Surf., B, 2013, 104, 133.

14 X. Wang, X. Liu and H. Han, Colloids Surf., B, 2013, 103, 136. 15 T. Akasaka, M. Matsuoka, T. Hashimoto, S. Abe, M. Uo and F. Watari, Mater. Sci. Eng., B, 2010, 173, 187.

16 S. Raimondi, E. Zanni, C. Talora, M. Rossi, C. Palleschi and D. Uccelletti, Appl. Environ. Microbiol., 2008, 74, 7130.

17 E. Zanni, G. De Bellis, M. P. Bracciale, A. Broggi, M. L. Santarelli, M. S. Sarto, C. Palleschi and D. Uccelletti, Nano Lett., 2012, 12, 2740.

18 R. J. Crawford, H. K. Webb, V. K. Truong, J. Hasan and E. P. Ivanova, Adv. Colloid Interface Sci., 2012, 142, 179182.

19 A. V. Singh, V. Vyas, R. Patil, V. Sharma, P. E. Scopelliti, G. Buongiorno, A. Podestà, C. Lenardi, W. N. Gade and P. Milani, PLoS One, 2011, 6, e25029.

20 T. J. Beveridge. Biotechnology and Bioengineering Symposium No. 16: Biotechnology for the Mining, Metal-Refining, and Fossil Fuel Processing Industries, Wiley Interscience, New York, 1986, pp. 127-140.

21 R. J. C. McLean and T. J. Beveridge, in Microbial Mineral Recovery, ed. H. L. Ehrlich and C. L. Brierley, McGraw-Hill, New York, 1990, pp 185-222.

22 D. F. Rodrigues and M. Elimelech, Environ. Sci. Technol., 2010, 44, 4583.

23 L. Dong, A. Henderson and C. Field, J. Nanotechnol., 2012, 2012, ID928924.

24 T. Akasaka and F. Watari, Acta Biomater., 2009, 5, 607. 25 S. Liu, A. K. Ng, R. Xu, J. Wei, C. M. Tan, Y. Yang and Y. Chen, Nanoscale, 2010, 2, 2744.

26 H. J. Busscher, R. J. B. Dijkstra, D. E. Langworthy, D. I. Collias, D. W. Bjorkquist, M. D. Mitchell and H. C. Van der Mei, J. Colloid Interface Sci., 2008, 322, 351.

27 H. Chen, B. Wang, D. Gao, M. Guan, L. Zheng, H. Ouyang, Z. Chai, Y. Zhao and W. Feng, Small, 2013, DOI: 10.1002/ smll.201202792.

28 M. Benincasa, S. Pacor, W. Wu, M. Prato, A. Bianco and R. Gennaro, ACS Nano, 2011, 5, 199. 